\title{
PELATIHAN KADER USAHA KESEHATAN SEKOLAH (UKS) PADA SISWA-SISWA MADRASAH ALIAH NEGERI (MAN) MODEL MANADO
}

\author{
Achmad Paturusi \\ Universitas Negeri Manado
}

\begin{abstract}
ABSTRAK
Peningkatan kesehatan masyarakat sekolah melalui pelatihan kader usaha kesehatan sekolah (UKS) pada siswa-siswa MAN Model Manado. Lokasi tempat pelaksanaan di Jl. Tuminting Raya. Kelurahan Tuminting Kecamatan Tuminting Kota Manado. Sekolah MAN Model Manado dengan kontribusi memberikan tempat pelayanan dan waktu kegiatan pengabdian kepada masyarakat serta keterlibatan siswa-siswa dan guru-guru Penjasorkes. Permasalahan yang ditemukan kurangnya pemahaman dan pengetahuan tentang pentingnya kesehatan masyarakat khususnya kesehatan masyarakat sekolah, olehnya dilakukan pelatihan kader-kader usaha kesehatan sekolah jasmani pada siswa-siswa MAN Model Manado. Kontribusi mendasar pada khalayak sasaran adalah terjadinya peningkatan kemampuan hidup sehat \& derajat kebugaran jasmani serta kesehatan peserta didik serta menciptakan lingkungan yang sehat, sehingga memungkinkan pertumbuhan \& perkembangan yang harmonis \& optimal dalam rangka pembentukan manusia Indoensia seutuhnya. Lebih khusus lagi adalah untuk memupuk kebiasaan hidup sehat \& mempertinggi derajat kesehatan peserta didik.
\end{abstract}

Kata kunci: Pelatihan Kader UKS 


\section{PENDAhULUAN}

Kesehatan merupakan dasar yang sangat diperlukan bagi keberhasilan melaksanakan pekerjaan. Dalam masalah kegiatan jasmani, manusia dalam hidupnya selalu dalam keadaan silih berganti antara istirahat dan bergerak. Sehat dalam kondisi aktif inilah yang sangat perlu dibina dan dipelihara. Oleh karena orang yang sehat dinamis, pasti sehat statis, tapi tidak untuk sebaliknya. Olahraga kesehatan hakekatnya meningkatkan derajat sehat dinamis yang adalah wujud dan kesegaran jasmani.

Program pembelajaran pendidikan jasmani merupakan upaya yang dilakukan dalam mewujudkan manusia Indonesia secara utuh baik dari segi pengetahuan, sikap dan ketrampilan. Pendidikan jasmani yang merupakan bagian integral dari pendidikan melalui aktifitas jasmani. Dengan pendidikan jasmani diharapkan peserta didik dapat meningkatkan pengetahuan, ketrampilan, sikap dan sosial yang baik. Penyelenggaraan pendidikan jasmani yang diselenggarakan pada semua jenis sekolah telah ditentukan atas dasar kurikulum yang diberlakukan, materi dalam kurikulum yang diberlakukan saat ini memuat aktifitas-aktifitas jasmani seperti permainan, atletik, senam, renang, aktifitas luar sekolah dan pendidikan kesehatan.

Pendidikan jasmani di sekolah pada masing-masing lembaga pendidikan diberikan dalam upaya membentuk manusia Indonesia seutuhnya, baik aspek pengetahuan, ketrampilan, sikap, emosi dan sosial. Kenyataan yang ada sekarang penilaian terhadap pendidikan jasmani kurang diperhatikan bahkan dikesampingkan. Bagaimana anak didik dapat menjadi manusia yang produktif apabila tidak didukung dengan kemampuan fisik yang cukup baik, karena kenyataan yang ada sekarang para orang tua hanya menuntut ananknya agar menjadi anak yang pintar dalam sisi pengetahuan saja tanpa memikirkan faktor yang lain diantaranya faktor fhysical fitness.

Sebagaimana diuraikan oleh Paturusi (2011:87) bahwa, "mata pelajaran Penjasorkes memiliki karakteristik yang berbeda dengan mata pelajaran lain. Perbedaan tersebut dapat dilihat dari tujuan yang ingin dicapai, materi yang disajikan, strategi yang digunakan, sarana prasarana, serta media yang digunakan untuk mencapai tujuan".

Tidak dapat dipungkiri bahwa semenjak lahir, manusia harus terus menerus bergerak untuk kelangsungan hidup, seorang dapat melakukan pekerjaan dengan baik apa bila ia mempunyai cukup kekuatan, daya tahan, keterampilan untuk melakukan pekerjaan. Banyak jenis aktifitas fisik yang dapat dilakukan manusia dalam pemenuhan kebutuhan hidupnya, yang tentunya harus ditunjang dengan keadaan fisik yang prima dan sehat. Dalam Era Globalisasi saat ini dan di masa yang akan datang, dibutuhkan sumberdaya manusia yang produktif serta siap untuk melaksanakan pembangunan nasional. Produktif yang tinggi dapat diwujudkan antara lain dengan meningkatkan derajat kesehatan dan kesegaran jasmani. Dalam dunia pendidikan sangat dibutuhkan kesehatan dan kesegaran jasmani para pelaku-pelakunya sebagai modal dasar dalam peningkatan mutu, prestasi dan produktif kerja. Tujuan pendidikan akan tercapai apabila para pelaku yang terlibat dalam bidang pendidikan memiliki tingkat kesegaran jasmani yang baik.

Perkembangan ilmu pengetahuan dan teknologi diberbagai bidang sebagai akibat dari proses dan hasil pendidikan, bukan hanya membawa dampak positif bagi manusia, tetapi juga membawa dampak negatif. Salah satu contoh dalam bidang transportasi, orang akan lebih memilih melakukan aktifitas dengan memanfaatkan kendaraan bermotor untuk sampai ketempat tujuan dengan cepat sehingga dapat menghemat waktu. Namun disadari atau tidak, aktifitas fisik yang dilakukan akan berkurang sehingga hal itu akan berdampak negatif pada kesegaran jasmani.

Menurut Suharto, dkk (2005:4)“ Kesegaran jasmani adalah kemampuan tubuh seorang untuk melakukan pekerjaan sehari-hari secara efektif dan efisien dalam jangka waktu yang relatif lama tanpa menimbulkan kelelahan yang berlebihan.” Selanjutnya Ngurah Nala (1998:7) mengemukakan bahwa "kesegaran jasmani adalah kemampuan tubuh untuk melakukan tugas rutin dalam jangka waktu yang cukup lama tanpa mengalami kelelahan yang berarti dan masih memiliki tenaga cadangan untuk melaksanakan aktifitas yang bersifat mendadak." Kesegaran jasmani seseorang dapat digambarkan melalui kondisi fisik saat melakukan aktifitas sehari-hari.

Bagi masyarakat sekolah khususnya siswa-siswa MAN Model Manado, bahwa tingkat kesegaran jasmani yang baik sangat diperlukan dalam proses belajar untuk memperoleh hasil belajar yang maksimal. Kesegaran jasmani dapat mempengaruhi hasil atau prestasi belajar sebab, dengan kondisi tubuh yang sehat dan segar orang akan mudah mengerti dan mencernah apa yang dipelajari atau yang diajarkan.

Seperti yang dikemukakan oleh Rusli Lutan (2001:24) bahwa: "kesegaran jasmani bermanfaat untuk menciptakan penampilan tubuh 
yang bagus dipandang membangkitkan kesan mampu melaksanakan tugas, dan percaya pada kemampuan diri bagi remaja dan dewasa, kesegaran jasmani dapat menjadikan mereka semakin cerdas dan cerah berpikir, serta siaga melakukan tugas."

Kesegaran jasmani pada siswa-siswa MAN Model Manado dapat ditingkatkan dan dipertahankan melalui pelaksanaan programprogram yang sesuai dengan kondisi fisik dan situasi siswa, baik program itu dilakukan secara umum atau kelembagaan, maupun secara perorangan atau individual. Namun sebenarnya, perlu diketahui secara pasti melalui tes dan pengukuran yang dilakukan dengan benar dan teliti.

Untuk dapat memastikan, maka penulis tertarik untuk melakukan pelatihan dalam rangka meningkatkan tingkat kesegaran jasmani pada siswa-siswa Madrasyah Aliah Negeri (MAN) Model I Manado.

\section{Permasalahan Mitra}

Masalah kesehatan masyarakat khususnya kesehatan masyarakat sekolah adalah faktor yang mendukung dalam proses pendidikan, bagaimana proses belajar mengajar dapat berjalan dengan baik apabila tidak didukung oleh semangat belajar para siswa-siswanya dengan baik, olehnya perlu adanya peningkatan kesegaran jasmani para peserta didik.

Bertolak dari hal tersebut, maka permasalahan dapat diidentifikasi sebagai berikut; Sejauh manakah pembinaan dan peningkatan kesegaran jasmani pada masyarakat khususnya pada siswa-siswa di sekolah, serta sejauhmana pendekatan dan penerapan ilmiah dalam peningkatan derajat kesehatan masyarakatnya? Apakah pembentukan kesegaran jasmani secara komprehensif turut mendukung dalam pencapaian derajat kesehatan sekolah? Bagaimanakah peranan pelatihan usaha kesehatan sekolah dalam pencapaian derajat kesehatan? Benarkah dengan pelatihan kesegaran jasmani pada siswa-siswa dapat mempermudah dan mendukung dalam peningkatan derajat hidup sehat dan dapat menunjang prestasi belajar siswa? Bagaimanakah pelatihan peningkatan kesegaran jasmani siswasiswa MAN Model Manado? Apakah dengan pelatihan dapat meningkatkan derajat hidup sehat dan dapat menunjang prestasi belajar yang lebih baik?

Dari analisa situasi yang ada, serta identifikasi masalah, maka permasalahan dalam pelatihan ini dapat dirumuskan sebagai berikut; peningkatan kesehatan masyarakat sekolah melalui pelatihan tingkat kesegaran jasmani pada siswasiswa MAN Model Manado.

\section{METODE}

\section{Metode Kegiatan}

Metode pelaksanaan kegiatan pengabdian ini yang dimaksud adalah berupa tahapan atau langkah-langkah dalam melaksanakan solusi yang ditawarkan untuk mengatasi permasalahan, yang antara lain dilakukan dengan metode pendekatan sebagai berikut:

$\checkmark$ Dibentuknya program pelatihan yang tepat pada anak-anak (siswa) lewat pelatihan tentang tingkat kesegaran jasmani.

$\checkmark$ Kegiatan yang dilakukan dengan bentukbentuk atau program pelatihan dapat dilakukan dengan; (1) tes lari cepat 60 meter, (2) tes angkat tubuh untuk putera 60 detik, (3) tes baring duduk 60 detik, (4) tes loncat tegak, dan (5) tes lari jauh untuk putera 1.200 meter.

$\checkmark$ Pemeriksaan kesehatan secara berkala, pemeriksaan kesehatan secara umum, pemeriksaan antropometri, melakukan aktivitas olahraga secara teratur, pemeliharaan \& pengawasan kebersihan lingkungan sekolah, pencegahan \& pemberantasan penyakit menular, usaha di bidang gizi, pengobatan ringan \& $\mathrm{P} 3 \mathrm{~K}$, merujuk pada pengobatan \& perawatan lebih lanjut.

$\checkmark$ Partisipasi didalam pelaksanaannya, pelayanan kesehaan disekolah dapat dilakukan oleh semua petugas kesehatan, serta dilakukan oleh guru-guru Penjasorkes.

\section{Prosedur Pelaksanaan Kegiatan}

Peningkatan kesehatan masyarakat sekolah melalui pelatihan kesegran jasmani pada siswasiswa MAN Model Manado dapat di evaluasi keberhasilannya dilakukan sebelum pelatihan dan sesudah pelatihan (pre-test and post-test) tentang program pelatihan kesegaran jasmani, adapun tahanpan pelaksanaan kegiatan sebagai berikut;

\section{> Tahap Perencanaan}

Tahapan ini dikerjakan setelah dilaksaakan analisa situasi terhadap tempat/lokasi kegiatan. Tahapan kegiatan ini dilakukan adalah tim pelaksana mengundang pihak sekolah dan peserta didik yang akan menjadi mitra untuk menjelaskan maksud dan tujuan kegiatan pengabdian kepada masyarakat sekolah serta mekanisme dan teknis pelaksanaan kegiatannya, yang 
dilanjutkan dengan tim pelaksana menyusun program pelatihan kesegaran jasmani dalam rangka peningkatan kesehatan masyarakat sekolah.

\section{> Tahap Pelaksanaan}

Pelaksanakan kegiatan dimasudkan yakni; pemeriksaan kesehatan secara berkala, pemeriksaan kesehatan secara umum, pemeriksaan antropometri, melakukan aktivitas olahraga secara teratur, pemeliharaan \& pengawasan kebersihan lingkungan sekolah, pencegahan \& pemberantasan penyakit menular, usaha di bidang gizi. Dibentuknya teknik pelaksanaan dengan tim yang menguasai program pelatihan, baik berupa;

(1) Tes lari cepat 60 meter,

(2) Tes angkat tubuh untuk putera 60 detik,

(3) Tes baring duduk 60 detik,

(4) Tes loncat tegak, dan

(5) Tes lari jauh 1.200 meter.

\section{$>$ Tahap Evaluasi dan Refleksi}

Evaluasi terhadap peserta ntuk diketahui sejauhmana pemahaman peserta terhadap program yang dijalankan. Refleksi dilakukan terhadap tingkat keberhasilan kegiatan program yang berjalan, sekaligus untuk mengetahui akan kekurangan dan kelebihan dari program yang telah dilaksanakan sebagai bentuk untuk menetapakan rekomendasi dan tindak lanjut program-program berikutnya.

\section{$>$ Tahap Pelaporan Hasil Kegiatan}

Setelah pelaksanaan selesai, maka dibuat laporan dari hasil kegiatan yang telah dilaksanakan, sebagai bentuk pertanggung jawaban terhadap kegiatan yang telah dilaksanakan.

\section{HASIL DAN PEMBAHASAN}

Hasil dari pengabdian ini adalah terjadinya peningkatan kesehatan masyarakat sekolah melalui pelatihan kesegaran jasmani pada siswa-siswa MAN Model Mnado terjadinya peningkatan lewat hasil pre-test dan post test.

Luaran yang dapat dihasilkan atau dicapai adalah terjadinya peningkatan tingkat kesegaran jasmani, sebagaimana hasil pengukuran status atau keadaan dari tingkat kesegaran jasmani pada siswa-siswa putera MAN Model Manado, baik pengukuran awal (pre-test) atau kondisi awal anak coba maupun pengukuran akhir (post-test) atau kondisi akhir anak coba setelah mendapatkan program pembelajaran penjasorkes, sebagaimana status atau keadaan dari tingkat kesegaran jasmani pada siswa-siswa putera MAN Model Manado tersebut secara umum menunjukkan masih berada dibawah norma standar penilaian tingkat kesegaran jasmani.

Tabel 1. Pemahaman Pendidikan Kesehatan Sekolah

\begin{tabular}{|l|l|l|l|}
\hline No & $\begin{array}{l}\text { Kriteria } \\
\text { Pemahaman }\end{array}$ & Frekuensi & $\begin{array}{l}\text { Frek. } \\
\text { Absolut }\end{array}$ \\
\hline 1 & $\begin{array}{l}\text { Sangat } \\
\text { kurang }\end{array}$ & - & - \\
\hline 2 & Kurang & - & - \\
\hline 3 & Cukup & 1 & $3,33 \%$ \\
\hline 4 & Baik & 22 & $73,33 \%$ \\
\hline 5 & Baik sekali & 7 & $23,34 \%$ \\
\hline & Jumlah & 30 & $100 \%$ \\
\hline
\end{tabular}

Selanjutnya berdasarkan kriteria penilaian capaian pada program pendidikan kesehatan siswa-siswa MAN Model Manado diperoleh hasil capaian berupa pemahaman pada menanamkan pengetahuan, pandangan \& kebiasaan hidup sehat kepada para siswa agar siswa berprilaku hidup sehat dan dapat ikut bertanggung jawab terhadap kesehatan diri sendiri dan kesehatan lingkungan lebih khusus lingkungan sekolah.

Dari hasil analisis capaian pada 30 siswa MAN Model Manado sebagaimana pada tabel 5.1 menunjukkan bahwa capaian peningkatan program pendidikan kesehatan siswa-siswa berada pada kelompok kategori baik sebanyak 22 siswa $(73,33$ $\%)$ siswa-siswa mendominasinya. Sedangkan untuk kategori cukup hanya 1 siswa $(3,33 \%)$, dan untuk kategori pemahaman pendidikan kesehatan baik sekali ada 7 siswa $(23,34 \%)$. Dari hasil ini dapat dikatakan bahwa nilai capaian pemahaman pengetahuan pendidikan kesehatan berada pada kelompok belajar dengan kategori baik.

\section{Tabel 2. Pelayanan Kesehatan di Sekolah}

\begin{tabular}{|l|l|l|l|l|l|}
\hline No & $\begin{array}{l}\text { Jenis } \\
\text { Kegiatan }\end{array}$ & Baik & Cukup & kurang & Ket \\
\hline 1 & $\begin{array}{l}\text { Pertumbuhan } \\
\text { \& } \\
\text { perkembangan } \\
\text { siswa }\end{array}$ & 23 & 4 & 3 & 30 \\
\hline 2 & $\begin{array}{l}\text { Pemeriksaan } \\
\text { kesehatan } \\
\text { sedini } \\
\text { mungkin }\end{array}$ & 22 & 7 & 1 & 30 \\
\hline
\end{tabular}




\begin{tabular}{|l|l|l|l|l|l|}
\hline 3 & $\begin{array}{l}\text { Penyakt } \\
\text { menular }\end{array}$ & - & - & - & - \\
\hline 4 & Pengobatan & - & - & - & - \\
\hline 5 & $\begin{array}{l}\text { Pengadaan } \\
\text { rehabilitasi }\end{array}$ & - & - & - & - \\
\hline & $\begin{array}{l}\text { Jumlah } \\
\text { Kegiatan }\end{array}$ & 45 & 11 & 4 & - \\
\hline
\end{tabular}

Selanjutnya berdasarkan penilaian capaian pada program pelayanan kesehatan di sekolah bertujuan mengetahui pertumbuhan \& perkembangan siswa, mengetahui bila ada kelainan gangguan kesehatan sedini mungkin, pencegahan penyakit menular, pengobatan secepat-cepatnya, rehabilitasi swa-siswa MAN Model Manado diperoleh hasil capaian berupa pelayanan kesehatan berjalan baik.

Dari hasil analisis capaian pada 30 siswa MAN Model sebagaimana pada tabel 5.2 menunjukkan bahwa capaian peningkatan program pelayanan di sekoah pada siswa-siswa hanya diadakan jenis kegiatan pemeriksaan pertumbuhan dan perkembangan siswa lewat pemeriksaan pengukuran antropometrinya, dimana hasil yang diperoleh pertumbuhan dan perkembangan siswa kategori baik sebanyak 23 siswa (76,67\%). Sedangkan untuk kategori cukup hanya 4 siswa $(13,33 \%)$, dan untuk kategori pertumbuhan dan perkembangan siswa kurang ada 3 siswa $(10,00 \%)$. Dari hasil ini dapat dikatakan bahwa nilai capaian pelayanan kesehatan di sekolah lewat pertumbuhan dan perkembangan siswa berada pada kelompok kategori baik.

Dari hasil analisis capaian pada 30 siswa MAN Model Manado sebagaimana pada tabel 5.2 menunjukkan bahwa capaian peningkatan program pelayanan kesehatan di sekolah siswa-siswa pada pemeriksaan kesehatan sedini mungkin berada pada kelompok kategori baik sebanyak 22 siswa $(73,33 \%)$ dimana siswa-siswa pada kategoori ini siswa mendominasinya. Sedangkan untuk kategori cukup hanya 1 siswa $(3,33 \%)$ pemeriksaan kesehatan sedini mungkin, dan untuk kategori pemeriksaan kesehatan sedini mungkin untuk baik sekali ada 7 siswa $(23,34 \%)$. Dari hasil ini dapat dikatakan bahwa nilai capaian pelayanan kesehatan di sekolah lewat pertumbuhan dan perkembangan siswa serta adanya pemeriksaan kesehatan sedini mungkin berada pada kelompok kategori baik.

Selanjutnya pelatihan usaha kesehatan sekolah lewat program lingkungan kehidupan sekolah yang sehat; meliputi lingkungan fisik \& mental (psikis), kriteria pemeriksaannya dapat dianalisis lewat program pemahaman pendidikan kesehatan di sekolah.
Luaran yang dapat dihasilkan atau dicapai adalah terjadinya peningkatan kemampuan hidup sehat \& derajat kesehatan peserta didik serta menciptakan lingkungan yang sehat, sehingga memungkinkan pertumbuhan \& perkembangan yang harmonis \& optimal dalam rangka pembentukan manusia Indoensia seutuhnya. Lebih khusus lagi adalah untuk memupuk kebiasaan hidup sehat \& mempertinggi derajat kesehatan peserta didik.

Hasil pengabdian lewat kegiatan program pelatihan usaha kesehatan sekolah (UKS) dapat pula menghasilkan luaran atau kontribusi pada;

- Publikasi ilmiah di jurnal / poster

- Peningkatan kesehatan masyarakat sekolah, pemahaman UKS \& peningkatan keterampilan bagi peserta didik tentang program-program UKS lewat evaluasi (pretest and post-test).

\section{KESIMPULAN}

Adapun beberapa kesimpulan yang dapat ditarik dari program pengembangan pelatihan kader-kader usaha kesehatan sekolah pada siswasiswa MAN Model Manado sebagai berikut;

- Dapat meningkatkan kemampuan membuat program pelatihan dasar, organisasi kesehatan sekolah serta dapat meningkatan pola hidup sehat.

- Diperolehnya peningkatkan dan pemahaman program pendidikan kesehatan pada setiap peserta.

- Diperolehnya peningkatkan dan pemahaman program pelayanan kesehatan di sekolah pada setiap peserta.

- Diperolehnya peningkatkan dan pemahaman program kehidupan lingkungan sekolah yang sehat pada setiap peserta.

- Diperoleh gambaran tentang peranan pelatihan kader usaha kesehatan sekolah untuk meningkatakan derajat kesehatan sekolah pada umumnya.

- Diperoleh data empirik tentang sistem pelatihan kader dalam pembinaan usaha kesehatan sekolah di MAN Model Manado.

- Dapat meningkatkan kemampuan hidup sehat \& derajat kesehatan peserta didik serta menciptakan lingkungan yang sehat, sehingga memungkinkan pertumbuhan \& perkembangan yang harmonis \& optimal dalam rangka pembentukan manusia Indoensia seutuhnya.

- Dapat memupuk kebiasaan hidup sehat \& mempertinggi derajat kesehatan peserta didik yang didalam mencakup; (a) memiliki 
pengetahuan, sikap \& keterampilan untuk melaksanaan prinsip hidup sehat, serta partisipasi aktif didalam usaha penigkatan kesehatan di sekolah, dirumah maupun lingkungan masyarakat, (b) sehat baik dalam arti fisik, mental, maupun social, dan (c) memiliki daya hayat dan daya tangkal terhadap pengaruh buruk, penyalahgunaan narkoba dan sebagainya.

\section{REFERENSI}

Anonimous. Undang-Undang No. 23 Tahun 1992 Tentang Kesehatan. Visimedia. Jakarta. 2007.

Depdikbud. Pendidikan Kesehatan. Direktorat Pendidikan Tinggi Proyek Pembinaan dan Pengembangan. Depdiknas. Jakarta 1996.

Depdikbud. Pedoman Pembinaan dan Pengembangan Usaha Kesehatan Sekolah (UKS). Jakarta 1995.

Harsono. Kepelatihan dan Aspek-Aspek Psikologi Dalam Kepelatihan, Depdikbud, P2LPTK, Jakarta 1988.

Maulana Heri d.J. Promosi Kesehatan. Penerbit Buku Kedokteran EGC. Jakarta. 2009.

Nala Ngurah. Prinsip Pelatihan Olahraga, Universitas Udayana, Denpasar 1998
Nurhasan. Tes dan Pengukuran Dalam Pendidikan Jasmani, Jakarta 1998.

Paturusi, A. Persediaan dan Permintaan Guru Penjas Suatu Tinjauan pada Manajemen Penjas. Proceeding, Unima Press, 2011.

Paturusi A. Pengukuran Dalam Bidang Pendidikan Jasmani dan Olahraga. IASPK Enterprise \& Printing. Manado 2011

Sajoto Mochamad. Pembinaan Kondisi Fisik Dalam Olahraga, Dep dikbud Dirjen Dikti Proyek Pengembangan LPTK, Jakarta 1988.

Subagyo. Awal Prestasi Melalui Pembelajaran Aquatik. Proceeding, Unima Press, 2011

Wirjasantosa Ratal. Supervisi Pendidikan Olahraga. UI Press, Jakarta 1990. 